\title{
Deposition and Transformation of Nitrogen after Soil Fumigation with Ethanedinitrile
}

\author{
Mary C. Stevens \\ Draslovka Services Group, North Melbourne, VIC 3051, Australia
}

\author{
Rui Yang \\ Institute of Urban Agriculture, Chinese Academy of Agricultural Sciences, \\ Chengdu 610200, China
}

\author{
Joshua H. Freeman \\ Department of Horticultural Sciences, University of Florida, North Florida \\ Research and Education Center, 155 Research Road, Quincy, FL 32351
}

Additional index words. methyl bromide alternatives, ammonium, nitrate

\begin{abstract}
A novel methyl bromide alternative, ethanedinitrile (EDN), has been reported to be efficacious against soil-borne pathogens, weeds, and plant-parasitic nematodes. Degradation products of EDN include $\mathrm{NH}_{4}{ }^{+}$and $\mathrm{NH}_{3}$, but it is currently unknown at what quantities these degradation products are being released into the soil at a given use rate of EDN. To address this issue, field studies were performed using the raised-bed plasticulture system. Deposition of $\mathrm{NH}_{4}{ }^{+}$and $\mathrm{NO}_{3}{ }^{-}$in top 0-15-, 15-30-, and 30-45-cm soils were evaluated 3 weeks after fumigation with EDN applied at 336, 448, and 560 $\mathrm{kg} \cdot \mathrm{ha}^{-1}$. Change of $\mathrm{pH}$ and transformation of $\mathrm{NH}_{4}{ }^{+}$to $\mathrm{NO}_{3}{ }^{-}$in top $0-15-$ and 15-30-cm soils were tracked weekly after fumigation with EDN at $448 \mathrm{~kg} \cdot \mathrm{ha}^{-1}$ for 10 weeks. This study found that fumigation with EDN significantly increased soil $\mathrm{pH}$ of the top $0-15-\mathrm{cm}$ soil and soil $\mathrm{NH}_{4}{ }^{+}$in top $0-15-$ and $15-30-\mathrm{cm}$ soils, but soil $\mathrm{NO}_{3}{ }^{-}$was unaffected. Nitrification process in top 0-15-cm soil was inhibited by fumigation with EDN for at least 7 weeks. These results indicate that $N$ deposited by fumigation with EDN could be an important preplant $N$ source for crop production, and the inhibition of nitrification could help mitigate nitrate leaching. This study provides helpful information for quantification of $\mathbf{N}$ deposited from fumigation with EDN.
\end{abstract}

Due to the ban on methyl bromide (MBr), the efficacy of old and new soil fumigants have been examined and developed further. A novel soil fumigant not currently labeled in the United States, ethanedinitrile (EDN), was initially examined for use as a fumigant to control insect pests in stored grain (Hooper et al., 2003). EDN has since been examined as a soil fumigant in the United States as well as other countries with acceptable efficacy against weed pests, plantparasitic nematodes, and soil-borne pathogens in a variety of crops such as tomato, carrot, and strawberry (Chung et al., 2007; Mattner et al., 2006; Park et al., 2014; Stevens et al., 2019). EDN has a high vapor pressure $(515 \mathrm{kPa})$ and low boiling point $\left(-21.1^{\circ} \mathrm{C}\right)$, which make it an ideal fumigant.

The chemical formula of EDN is $\mathrm{C}_{2} \mathrm{~N}_{2}$, and some degradation products are $\mathrm{NH}_{4}{ }^{+}$, $\mathrm{NH}_{3}, \mathrm{CO}_{2}$, and $\mathrm{HCO}^{-}$. It is currently un-

Received for publication 27 Aug. 2020. Accepted for publication 13 Oct. 2020.

Published online 10 November 2020.

Funding for this research was provided by USDA NIFA Award 2016-51102-25814.

J.H.F. is the corresponding author. E-mail: joshuafr@ufl.edu.

This is an open access article distributed under the CC BY-NC-ND license (https://creativecommons. org/licenses/by-nc-nd/4.0/). known at what quantities plant-available nitrogen species are being released into the soil at a given use rate of EDN. The deposition of ammonium by EDN could be beneficial, because ammonium is commonly used as a source of nitrogen in fertilizer blends applied by vegetable producers. However, toxicity to some vegetable crops can occur because of an overabundance of ammonium (Simonne et al., 1992). Furthermore, ammonium is converted to nitrate in the soil by nitrifying bacteria. Under conditions that predominate in Florida, most of the soil $\mathrm{N}$ is quickly converted to $\mathrm{NO}_{3}{ }^{-}$, regardless of the originally applied form (Zotarelli et al., 2009). As a negatively charged ion, nitrate may not be readily retained by soil particles (Scharf, 2015). Nitrate also moves freely with water, because it is highly soluble. These characteristics lead to increased tendency of nitrate leaching and runoff, and potential surface water and groundwater contamination (Marchi et al., 2016), which could harm livestock and lead to eutrophication in aquatic ecosystems (Rios et al., 2013).

In Florida, many high-value crops such as tomato, pepper, and watermelon require high inputs of fertilizer and irrigation on sandy soils that have low nutrient and water retention capacity. These crops are typically grown in fumigated soil, on plastic mulch; and drip irrigation is used to deliver water and fertilizer, which increases efficacy of nutrient delivery and reduces evaporation (Liu et al., 2020). Because water delivers the fertilizer, it is increasingly important to keep water primarily in the root zone to reduce leaching and runoff, which could lead to higher production costs and negative environmental impacts. Florida vegetable producers are encouraged to enroll in the best management practices (BMPs) program, which is proven to be the most effective means for proper water and fertilizer use, and for maintaining or improving the quality of ground and surface waters (FDACS, 2015). For Florida vegetable producers to comply with BMPs and mitigate potential of nitrate leaching into the groundwater, it is important to assess the deposition of nitrogen by EDN.

One area of concern regarding soil fumigants is their impact on soil microbes, some of which are responsible for nitrogen transformation (Ibekwe et al., 2001). Generally, a significant increase of ammonium is observed immediately following application of a soil fumigant because of the mineralization of killed microbial biomass (De Neve et al., 2004; Shen et al., 1984). Nitrification is also impacted from the loss of nitrifying bacteria, resulting in reduced nitrate and a further accumulation of ammonium (Duniway, 2002; Jenkinson and Powlson 1970; Macnish 1986; Shen et al., 1984; Zhang et al., 2011). Yan et al. (2013) found that fumigation with $\mathrm{MBr}$ and methyl iodide inhibited nitrification by $43.4 \%$ and $37.2 \%$, respectively, for up to 4 weeks. Another study found that fumigation with 1,3-dichloropropene inhibited nitrification for 8 weeks (Zhang et al., 2011). Preliminary data gathered during efficacy studies with EDN indicated that plant-available nitrogen species, primarily ammonium, were increasing after EDN application - but confounding factors did not allow for investigation of this subject during these experiments (Stevens et al., 2019). At this time, it is unclear what effect an ammonium-depositing soil fumigant will have on soil nitrogen transformations and total nitrogen deposition. This study aimed to assess ammonium deposition and its subsequent transformation to nitrate after application of EDN.

\section{Materials and Methods}

A field trial was conducted at the University of Florida North Florida Research and Education Center (NFREC) in Quincy, FL (lat. $30.54{ }^{\circ} \mathrm{N}$, long. $84.60{ }^{\circ} \mathrm{W}$ ) and was repeated three times: Spring 2018, Fall 2018, and Spring 2019. Duration, soil type and taxonomy, average soil temperature, and total rainfall of the three field seasons were listed in Table 1. Before the establishment of this study, each field was fallowed for at least one growing season and no fertilizer was applied. The experimental design was a randomized complete block design with four replications. Treatments included fumigation with EDN (99\% liquid product, molecular weight $52.03 \mathrm{~g} / \mathrm{mol}$ ) (Lučební závody 
Table 1. Duration, soil type and taxonomy, average soil temperature $(15 \mathrm{~cm})$, and total rainfall of the three field seasons including Spring and Fall 2018 and Spring 2019 in Quincy, FL.

\begin{tabular}{|c|c|c|c|c|c|c|}
\hline Season & Duration & Soil type & Soil taxonomy & $\begin{array}{c}\text { Soil organic } \\
\text { matter }\end{array}$ & $\begin{array}{l}\text { Avg soil } \\
\text { temp }{ }^{\circ} \mathrm{C}\end{array}$ & $\begin{array}{c}\text { Total } \\
\text { rainfall } \mathrm{mm}\end{array}$ \\
\hline Spring 2018 & 28 Mar.-6 May & Orangeburg-Norfolk complex & fine-loamy, kaolinitic, thermic Typic Kandiudults & $0.79 \%$ & 21.8 & 326 \\
\hline Fall 2018 & 23 Aug.-1 Oct. & Dothan-Fuquay complex & loamy, kaolinitic, thermic Arenic Plinthic Kandiudults & $0.67 \%$ & 24.5 & 244 \\
\hline Spring 2019 & 11 Mar.-20 May & Orangeburg-Norfolk complex & fine-loamy, kaolinitic, thermic Typic Kandiudults & $0.87 \%$ & 20.0 & 224 \\
\hline
\end{tabular}

Draslovka, Kolín, Czech Republic) at 336, 448 , and $560 \mathrm{~kg} \cdot \mathrm{ha}^{-1}$. The EDN molecule is roughly $53 \%$ nitrogen. All treatments were applied as a liquid, which quickly vaporizes, under 0.32-mm thick, white-on-black, totally impermeable film (Guardian Agricultural Plastics Corporation, Tampa, FL), using shank injection $25 \mathrm{~cm}$ below the soil surface with two "super sealer" shanks (Wiese Industries, Perry, IA) spaced 25 $\mathrm{cm}$ apart. Soil was cultivated to a depth of $25 \mathrm{~cm}$ before fumigation, and soil moisture was at least $75 \%$ field capacity. Fields used for these experiments were maintained in a clean, fallow state for at least 1 month before fumigation. The black-and-white side of the film showed for Spring and Fall seasons, respectively, which is typical of commercial production. Bed formation, fumigant application, and plastic deployment were accomplished with a single-row, combination bed press, where all three operations are performed at the same time. Bed dimensions of experimental plots were 76.2 $\mathrm{cm}$ wide and $20 \mathrm{~cm}$ high, with $1.8-\mathrm{m}$ row spacing. No crops were planted into experimental plots, and no irrigation water was added after fumigation.

Two separate sampling regimes and analyses were performed on established experimental plots. One was established to investigate where and at what quantity plant-available nitrogen species may be deposited as impacted by EDN use rate. Another was established to determine how disruption of soil microbes by EDN application may alter the transformation of nitrogen species deposited by EDN.

For the nitrogen deposition study, two top $45-\mathrm{cm}$ soil samples with a diameter of $4 \mathrm{~cm}$ were taken in each plot, in the center of each bed, with a Geoprobe (Geoprobe Systems, Salina, KS) 1 day before ("Pre") and 3 weeks after ("Post") fumigation. Each soil sample was separated into $0-15-\mathrm{cm}, 15-30-\mathrm{cm}$, and $30-45-\mathrm{cm}$ sections. The two samples from each plot were then thoroughly mixed as a composite sample. Soil $\mathrm{pH}, \mathrm{NO}_{3}{ }^{-}$, and $\mathrm{NH}_{4}{ }^{+}$ at each depth were analyzed by a commercial laboratory. Briefly, soil $\mathrm{NH}_{4}{ }^{+}$and $\mathrm{NO}_{3}{ }^{-}$ions were extracted by $2 \mathrm{M} \mathrm{KCl}$ solution from fresh soil using a 1:10 soil/solution ratio (w/ v) and determined by flow injection analyzer. Soil $\mathrm{pH}$ was analyzed by an automated analyzer using a 1:1 soil/water ratio (v:v). Transformation of nitrogen was determined by taking two top $30-\mathrm{cm}$ soil samples from plots treated with $448 \mathrm{~kg} \cdot \mathrm{ha}^{-1}$ EDN on a weekly basis for 10 weeks. The top $30 \mathrm{~cm}$ of soil was used because any nitrogen deposited below this depth would likely never be used by crop species. The use rate of $448 \mathrm{~kg} \cdot \mathrm{ha}^{-1}$ was chosen based on previous efficacy studies on soil-borne pests. Soil samples were separated into $0-15-\mathrm{cm}$ and $15-30-\mathrm{cm}$ sections for $\mathrm{pH}, \mathrm{NO}_{3}{ }^{-}$, and $\mathrm{NH}_{4}{ }^{+}$ion analysis using the above-described methods. Week 7 data in the Fall 2018 season were missing due to a significant weather event (i.e., Hurricane "Michael") that impacted the area.

Data were analyzed using mixed model methodology. EDN rate was treated as a fixed effect, while sampling dates and soil depth were treated as double repeated measures. Covariance matrix for sampling date and soil depth was unstructured and first-order auto regressive, respectively. Random effects included season, block, and their interactions with other factors. To test for differences among EDN rates, sampling dates, soil depth, and their interactions, Bonferroni's post hoc test was performed using SAS 9.4 software at $\alpha=0.05$ level (SAS Institute Inc., Cary, NC). Figures were composed using SigmaPlot 14.0 software (Systat Software, San Jose, CA).

\section{Results}

Nitrogen deposition. Soil $\mathrm{pH}$ of the top 0 $15-\mathrm{cm}$ soil significantly increased from 6.3 6.4 before fumigation to $7.0-7.1$ at 3 weeks after fumigation (WAF). However, fumigation had minimal impacts on $\mathrm{pH}$ of the deeper soil profile (i.e., $15-30$ and $30-45 \mathrm{~cm}$ ). No significant differences were observed among the three EDN rates regarding their impacts on soil $\mathrm{pH}$ at $3 \mathrm{WAF}$ (Table 2).

Fumigation with EDN notably increased soil $\mathrm{NH}_{4}^{+}$concentration in top $0-15$ - and 15 $30-\mathrm{cm}$ soils, but not in $30-45-\mathrm{cm}$ soils (Table 2). At $3 \mathrm{WAF}, \mathrm{NH}_{4}^{+}$concentration showed a significant increase between 448 and $560 \mathrm{~kg} \cdot \mathrm{ha}^{-1}\left(34.8\right.$ and $40.0 \mathrm{mg} \cdot \mathrm{kg}^{-1}$ soil, respectively) at $0-15 \mathrm{~cm}$, whereas concentrations were similar between 336 and 448 $\mathrm{kg} \cdot \mathrm{ha}^{-1}$. A similar trend was observed at 15 $30 \mathrm{~cm}$, but the differences among EDN rates did not reach a significant statistical level. No significant differences were detected among EDN rates at $30-45 \mathrm{~cm}$ for $\mathrm{NH}_{4}{ }^{+}$concentration (Table 2).

Soil $\mathrm{NO}_{3}{ }^{-}$concentration did not significantly change at 3 WAF across all the evaluated soil profiles, relative to the background concentration. No significant differences among EDN rates were observed either, regardless of soil depth (Table 2).

Nitrogen transformation. Soil $\mathrm{pH}$ significantly increased from 0 to 1 WAF and remained relatively consistent for the rest of the season at $0-15 \mathrm{~cm}$. The $15-30-\mathrm{cm}$ soils had notably lower soil $\mathrm{pH}$ compared with the top $0-15-\mathrm{cm}$ soil, and fumigation with EDN had minimal effect on soil $\mathrm{pH}$ at $15-30 \mathrm{~cm}$ (Fig. 1).

Soil $\mathrm{NH}_{4}{ }^{+}$concentration significantly increased from $2.8 \mathrm{mg} \cdot \mathrm{kg}^{-1}$ at $0 \mathrm{WAF}$ to 38.5 $\mathrm{mg} \cdot \mathrm{kg}^{-1}$ at $1 \mathrm{WAF}$ at $0-15 \mathrm{~cm}$. Following the initially sharp increase, $\mathrm{NH}_{4}{ }^{+}$level continued to slowly increase until reaching its peak concentration at $7 \mathrm{WAF}$. After that, soil $\mathrm{NH}_{4}{ }^{+}$ concentration started to decline sharply. Soil $\mathrm{NH}_{4}^{+}$concentration eventually (i.e., 10 WAF) dropped to a level similar to 3-4 WAF (Fig. 2A). A similar trend also applied to soil $\mathrm{NH}_{4}^{+}$concentration at $15-30 \mathrm{~cm}$ (Fig. 2B).

Unlike soil $\mathrm{NH}_{4}{ }^{+}$, soil $\mathrm{NO}_{3}{ }^{-}$concentration remained relatively consistent from 0 to 7 WAF and linearly increased afterward in both 0-15- and 15-30-cm soils. Compared with $0 \mathrm{WAF}$, soil $\mathrm{NO}_{3}{ }^{-}$concentration at 10 WAF significantly increased by 6- and 4times in $0-15$ and $15-30 \mathrm{~cm}$, respectively (Fig. 2A and B). Soil $\mathrm{NH}_{4}{ }^{+}$and $\mathrm{NO}_{3}{ }^{-}$may continue to change beyond the duration of the current study.

A comparison of $\mathrm{NO}_{3}{ }^{-}$and $\mathrm{NH}_{4}{ }^{+}$at each soil depth was analyzed to determine the effect of EDN on nitrification. Before fumigation (i.e., $0 \mathrm{WAF}$ ), no significant differences were observed between $\mathrm{NO}_{3}{ }^{-}$and $\mathrm{NH}_{4}{ }^{+}$ at both soil depths (Fig. 2A and B). At 0-15 $\mathrm{cm}$, soil $\mathrm{NH}_{4}^{+}$concentration was consistently greater than soil $\mathrm{NO}_{3}{ }^{-}$concentration from 1 to 10 WAF (Fig. 2A). In contrast, significant differences between soil $\mathrm{NH}_{4}{ }^{+}$and $\mathrm{NO}_{3}{ }^{-}$ concentration at $15-30 \mathrm{~cm}$ only occurred between 6 and 8 WAF (Fig. 2B).

\section{Discussion}

Due to the nonselective nature of soil fumigants, effects on soil microbes are typically observed, including those responsible for transformation of nitrogen. Soil fumigation often results in an increase of $\mathrm{NH}_{4}{ }^{+}$ released from the killed microbial biomass and can remain in an unoxidized state until nitrifying bacteria reestablish sufficient populations to oxidize $\mathrm{NH}_{4}{ }^{+}$(Jenkinson and Powlson, 1970; Rovira, 1975; Shen et al., 1984).

One objective of this study was to determine deposition of nitrogen by EDN at different rates. It is well known that $\mathrm{NH}_{4}{ }^{+}$is a degradation product of EDN; therefore, this was done by analyzing average $\mathrm{NH}_{4}^{+}$concentration for each rate at $3 \mathrm{WAF}$. We observed $\mathrm{NH}_{4}{ }^{+}$levels ranging from 42.3$54.9 \mathrm{mg} \cdot \mathrm{kg}^{-1}$ at $3 \mathrm{WAF}$ in soils that had no fertilizer applied before fumigation. Thus it 


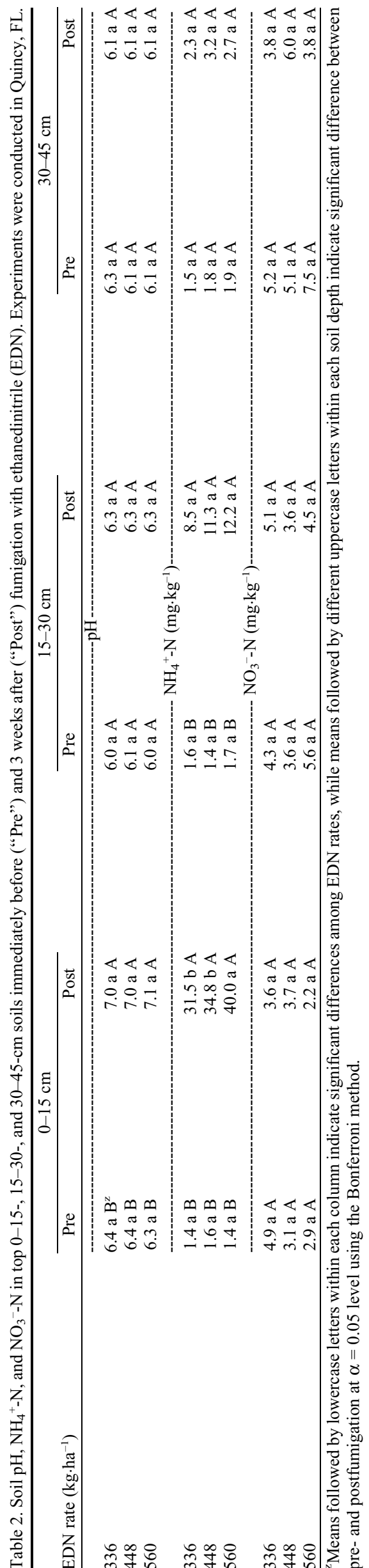

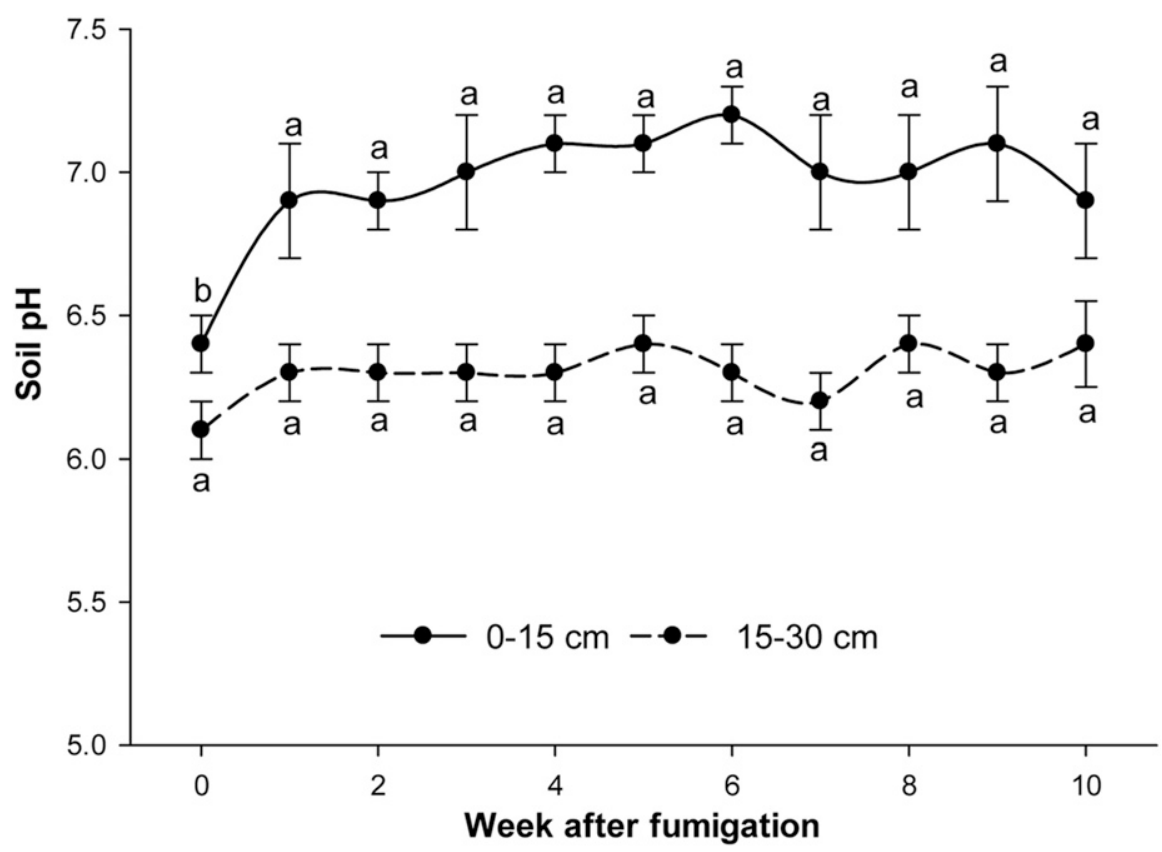

Fig. 1. Soil $\mathrm{pH}$ in top $0-15$ - and $15-30-\mathrm{cm}$ soils immediately before and weekly after fumigation with 448 $\mathrm{kg} \cdot \mathrm{ha}^{-1}$ ethanedinitrile $(E D N)$. Data represent means $\pm \mathrm{sE}$. Different lowercase letters indicate significant differences among sampling dates for each soil depth.

may be reasonably assumed that the $\mathrm{NH}_{4}^{+}$ measured at this time resulted from the application of EDN. There was a significant increase in ammonium deposition between 448 and $560 \mathrm{~kg} \cdot \mathrm{ha}^{-1}$ but not between 336 and $448 \mathrm{~kg} \cdot \mathrm{ha}^{-1}$, though the percentage increase was similar between both rate increases. Ammonium deposition clearly increases with EDN use rate, but the three rates used in this study are most likely to be deployed commercially because of the pest control efficacy.

Most of the significant effects observed during these experiments were in the top 30 $\mathrm{cm}$ of the soil profile; indeed the most profound effects were observed in the top $15 \mathrm{~cm}$. Because of the volatile nature of EDN, it is hard to track its movement within the soil profile. Because of its high vapor pressure, it has been hypothesized that EDN will move extensively in the soil profile. While this may be the case, fumigant vapor will eventually move toward the soil surface, and it may not reside long enough at these depths for complete transformation from the EDN molecule into its byproducts.

Transplanting of vegetable crops typically occurs 3 WAF. At this time, soil $\mathrm{NH}_{4}^{+}-\mathrm{N}$ of $40.0 \mathrm{mg} \cdot \mathrm{kg}^{-1}$ (equivalent to $\approx 90$ $\mathrm{kg} \cdot \mathrm{ha}^{-1}$ ) was detected at the lowest rate of EDN, which exceeds the recommended rate of preplant $\mathrm{N}$ fertilizer for crops such as tomato and pepper $\left(\approx 78.5 \mathrm{~kg} \cdot \mathrm{ha}^{-1}\right)$ for Florida production systems (Liu et al., 2020). These data suggest that fumigation with EDN has the potential to eliminate application of preplant $\mathrm{N}$ fertilizer for some crops. Meanwhile, use of EDN could result in excessive preplant nitrogen, which could be detrimental for some crops, such as strawberry, be- cause excess nitrogen can cause the plant to produce too many runners, fewer flowers, and poor-quality fruit (Hochmuth et al., 1996). Average soil $\mathrm{NH}_{4}{ }^{+}$deposited by EDN fumigation was $47.7 \mathrm{mg} \cdot \mathrm{kg}^{-1}$, which could save producers $\$ 38.37$ per acre in nitrogen fertilizer costs compared with the use of urea fertilizer (B. Lanier, personal communication).

Nitrification of $\mathrm{NH}_{4}{ }^{+}$is an important step in the nitrogen cycle. In one study, $\mathrm{NH}_{4}{ }^{+}$ added to unfumigated soil was nitrified within 1 week, while fumigated soil inhibited nitrification for at least 3 weeks in all evaluated soil types (De Neve et al., 2004). In the current study, inhibition of nitrification occurred for at least 7 weeks. The difference in nitrification inhibition could be due to the slightly different soil types because fumigant movement is highly dependent on soil type and could affect microbial recolonization. A depression of nitrification for 4 months due to fumigation with a dichloropropene-containing fumigant in loamy sand soil was previously reported (Draycott and Last, 1971). Fumigation with the same dichloropropene-containing fumigant on a sandy loam soil depressed nitrification for 3 weeks in another study (Tu, 1993, 1994).

De Neve et al. (2004) reported peak $\mathrm{NH}_{4}{ }^{+}$levels in fumigated soil at $5 \mathrm{WAF}$, followed by a sharp decline. In the current study, peak $\mathrm{NH}_{4}{ }^{+}$levels occurred 2 weeks later (i.e., $7 \mathrm{WAF}$ ) before it started to decrease. This suggests nitrification is inhibited for an increased period in these soils when EDN is applied. In coursetextured soils, decreased conversion of $\mathrm{NH}_{4}{ }^{+}$to $\mathrm{NO}_{3}{ }^{-}$could have a positive impact, because these soils have a high leaching potential. However, nitrification inhibition 

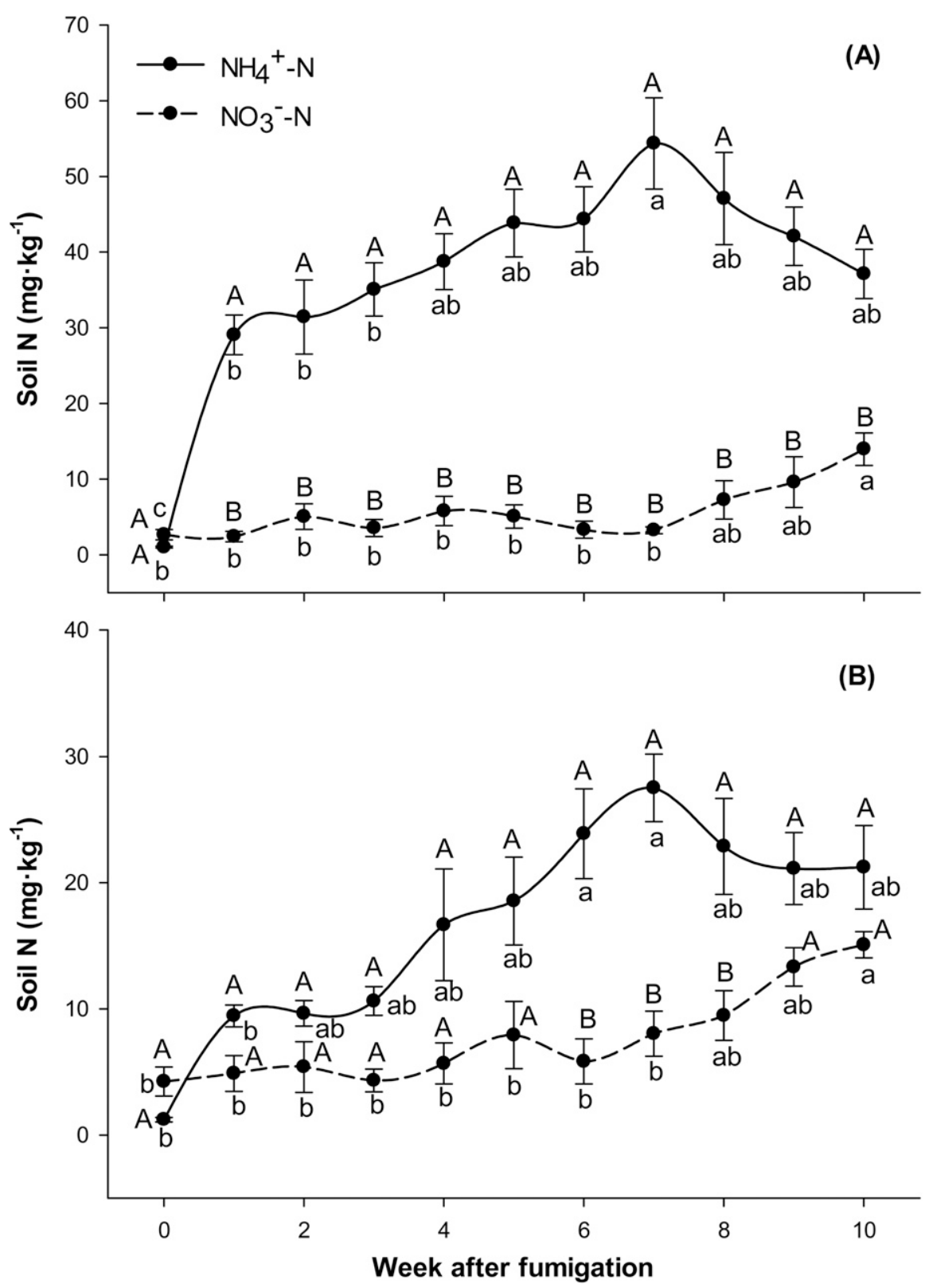

Fig. 2. Soil $\mathrm{NH}_{4}{ }^{+}-\mathrm{N}$ and $\mathrm{NO}_{3}{ }^{-}-\mathrm{N}$ in top (A) $0-15-$ and (B) $15-30-\mathrm{cm}$ soils immediately before and weekly after fumigation with $448 \mathrm{~kg} \cdot \mathrm{ha}^{-1}$ ethanedinitrile (EDN). Data represent means $\pm \mathrm{SE}$. Different lowercase letters indicate significant differences among sampling dates for $\mathrm{NH}_{4}{ }^{+}-\mathrm{N}$ or $\mathrm{NO}_{3}{ }^{-} \mathrm{N}$, whereas different uppercase letters indicate significant differences between $\mathrm{NH}_{4}{ }^{+}-\mathrm{N}^{-}$and $\mathrm{NO}_{3}{ }^{-}-\mathrm{N}$ at each sampling date.

could also have a detrimental impact because high ammonium concentration could cause toxicity or compete for binding sites in the soils with other cationic nutrients (e.g., $\mathrm{K}^{+}$), leading to potential nutrient deficiencies.

As also shown in previous studies, fumigation in this study resulted in significant change in nitrification. Fumigation with EDN results in deposition of $\mathrm{NH}_{4}{ }^{+}$; however, the amount of ammonium deposited by EDN is still variable. Transformation of $\mathrm{NH}_{4}{ }^{+}$to $\mathrm{NO}_{3}{ }^{-}$was inhibited for at least 7 weeks. This could be impacted by planting a crop, or the addition of irrigation, which will introduce new microbes to the fumigated bed and may speed microbial recolonization.
FDACS. 2015. Water quality/quantity best management practices for Florida vegetable and agronomic crops. Univ. Fl. Inst. of Food and Agr. Sci. Ext. Pub. P-01266.

Hochmuth, G.J., E.E. Albregts, C.C. Chandler, J. Cornell, and J. Harrison. 1996. Nitrogen fertigation requirements of drip-irrigated strawberries. J. Amer. Soc. Hort. Sci. 121:660-665, doi: 10.21273/JASHS.121.4.660.

Hooper, J.L., J.M. Desmarchelier, Y. Ren, and S.E. Allen. 2003. Toxicity of cyanogen to insects of stored grain. Pest Manag. Sci. 59:353-357, doi: 10.1002/ps.648.

Ibekwe, A.M., S.K. Papiernik, J. Gan, C. Yang, D.E. Crowley, and S.R. Yates. 2001. Impact of fumigants on soil microbial communities. Appl. Environ. Microbiol. 67:3245-3257.

Jenkinson, D.S. and D.S. Powlson. 1970. Residual effects of soil fumigation on soil respiration and mineralization. Soil Biol. Biochem. 2:99108.

Liu, G.D., E.H. Simonne, K.T. Morgan, G.J. Hochmuth, S. Agehara, and R. Mylavarapu. 2020. Fertilizer management for vegetable production in Florida, p. 3-9. In: P. Dittmar, J. Freeman, M. Paret, and H. Smith (eds.). Vegetable production handbook of Florida 20192020. Univ. of Fl. Inst. of Food and Agr. Sci.

Macnish, G.C. 1986. Effects of fumigation on soil nitrogen, plant nitrogen and root disease incidence in wheat at Wongan Hills, Western Australia. Austral. J. Soil Res. 24:81-93.

Marchi, E.C.S., L. Zotarelli, J.A. Delgado, D.L. Rowland, and G. Marchi. 2016. Use of the Nitrogen Index to assess nitrate leaching and water drainage from plastic-mulched horticultural cropping systems of Florida. Ints. Soil Water Conserv. Res. 4:237-244, doi: 10.1016/ j.iswcr.2016.12.001.

Mattner, S.W., R.K. Gounder, R.C. Mann, I.J. Porter, J.N. Matthiessen, Y.L. Ren, and M. Sarwar. 2006. Ethanedinitrile $\left(\mathrm{C}_{2} \mathrm{~N}_{2}\right)-A$ novel soil fumigant for strawberry production. Acta Hort. 708:197-203, doi: 10.17660/ActaHortic. 2006.708.32.

De Neve, S., G. Csitári, J. Salomez, and G. Hofman. 2004. Quantification of the effect of fumigation on short- and long-term nitrogen mineralization and nitrification in different soils. J. Environ. Qual. 33:1647-1652, doi: 10.2134/ jeq2004.1647.

Park, C.G., J. Son, B. Lee, J.H. Cho, and Y.L. Ren 2014. Comparison of ethanedinitrile $\left(\mathrm{C}_{2} \mathrm{~N}_{2}\right)$ and metam sodium for control of Bursaphelenchus xylophilus (Nematoda: Aphelenchidae) and Monochanus alternatus (Coleoptera: Cerambycidae) in naturally infested $\operatorname{logs}$ at low temperatures. J. Econ. Entomol. 107:20552060, doi: 10.1603/EC14009.

Rios, J.F., M. Ye, L. Wang, P.Z. Lee, H. Davis, and R. Hicks. 2013. ArcNLET: A GIS-based software to simulate groundwater nitrate load from septic systems to surface water bodies. Comput. Geosci. 52:108-116, doi: 10.1016/j.cageo.2012. 10.003 .

Rovira, A.D. 1975. Studies on soil fumigation-I, Effects on ammonium, nitrate and phosphate in soil and on the growth, nutrition and yield of wheat. Soil Biol. Biochem. 8:241-247.

Scharf, P.C. 2015. Understanding nitrogen, p. 124. In: Managing nitrogen in crop production. Amer. Soc. of Agron., Madison, WI.

Shen, S.M., G. Pruden, and D.S. Jenkinson. 1984. Mineralization and immobilization of nitrogen in fumigated soil and the measurement of microbial biomass nitrogen. Soil Biol. Biochem. 16:437-444. 
Simonne, E., H.A. Mills, and D.A. Smittle. 1992. Ammonium reduces growth, fruit yield and fruit quality of watermelon. J. Plant Nutr. 15:27272741, doi: 10.1080/01904169209364505.

Stevens, M.C., J.H. Freeman, and N.S. Boyd. 2019. Impact of ethanedinitrile rates and application method on nutsedge species and tomato root galling. Crop Prot. 116:1-6, doi: 10.1016/j.cropro.2018.10.001.

Tu, C.M. 1993. Effect of nematicides, Telone II and Vorlex, on microflora and nitrification in tobacco soil. Bull. Environ. Contam. Toxicol. 50:43-48, doi: 10.1007/BF00196539.

Tu, C.M. 1994. Effects of herbicides and fumigants on microbial activities in soil. Bull. Environ. Contam. Toxicol. 53:12-17, doi: 10.1007/ BF00205132.

Yan, D., Q. Wang, L. Mao, T. Ma, Y. Li, M. Guo, and A. Cao. 2013. Nitrification dynamics in a soil after addition of different fumigants. Soil Sci. Plant Nutr. 59:142-148, doi: 10.1080 00380768.2012 .754727 .
Zhang, C., G. Li, Q. Lin, A. Cao, and X. Zhao. 2011. The dynamics of dissolved organic $\mathrm{N}$ in the fumigated soils. Biol. Fertil. Soils 47:833837, doi: 10.1007/s00374-011-0544-6.

Zotarelli, L., M.D. Dukes, J.M.S. Scholberg, R. Muñoz-Carpena, and J. Icerman. 2009. Tomato nitrogen accumulation and fertilizer use efficiency on a sandy soil, as affected by nitrogen rate and irrigation scheduling. Agr. Water Manage. 96:1247-1258, doi: 10.1016/j.agwat. 2009.03.019. 